\title{
Participatory Evaluation of Some Tomato Genotypes for Resistance to Bacterial Wilt
}

\author{
Ram D. Timila* and Sharada Joshi \\ Plant Pathology Division, Nepal Agricultural Research Council, Khumaltar, Lalitpur, Nepal \\ $<$ rdevi04@yahoo.com>
}

\begin{abstract}
Bacterial wilt caused by Ralstonia solanacearum E.F. Smith is one of the destructive diseases of tomato. Experiments were conducted to confirm the resistance and to evaluate varieties received from Asian Vegetable Research and Development Center against bacterial wilt disease in the farmers' bacterial wilt sick fields at Thaiba and at Panchkhal during 1999 and 2000-2001 respectively. A total of five varieties such as CLN 2026 C, CLN 2026 D, CLN 1466 J, CLN 1466 P and susceptible check Lapsigede or L 390 were included in the experiments. Randomized complete block design with 4 replications was commenced at both the locations. In terms of disease incidence and yield parameters as well as consumers' preference on the fruit size, CLN 2026 C was found the best variety followed by CLN 2026 D. Wilt incidence was significantly lower in those varieties showing resistant reaction than in susceptible check. However, the marketable fruit yields were significantly higher with low wilt incidences in CLN 1466 P and CLN $1466 \mathrm{~J}$ also compared to susceptible check. But the large fruit size of those varieties was not acceptable to the consumers and the growers. Thus, CLN 2026 C and CLN 2026 D could be used as resistant variety to minimize crop losses from bacterial wilt disease.
\end{abstract}

Key words: Bacterial wilt, Ralstonia solanacearum, resistant variety, Tomato

\section{INTRODUCTION}

Bacterial wilt caused by Ralstonia solanacearum E.F. Smith (RS) is widely distributed disease in the world. It is one of the limiting factors to the successful cultivation of solnaceous vegetables throughout the world, where warm and humid climate is prevalent (Kelman 1953, Vawdrey and Gounder 1993). In Nepal, Tomato (Lycopersicon esculentum L.) is one of the fruit vegetables grown extensively in terai, foothills and valleys of Nepal. After late blight, bacterial wilt is considered to be the second most important disease in tomato. In Nepal, it was first recorded in 1978 in tomato crop (Shrestha 1990) and proved to be one of the limiting factors for successful cultivation in lowlands, foothills and valleys. Its incidence was reported as high as $80 \%$ causing considerable yield losses in tomato growing areas of Nepal (Timila et al 1997). The primary source of inoculum for the occurrence and spread of the pathogen is considered to be infested soil, plant debris and weeds (Kelman 1953). Bacterial wilt is difficult to control, once established in the field because of soil borne nature of the pathogen, and having wide host range, wide spread distribution and vast genetic variability of the pathogen (Hayward 1991). In recent years, RS is reported to be capable of infecting more than 50 botanical families with more than 200 plant species (Marco et al 2005). Due to the limited efficacy of current integrated management strategies of bacterial wilt, this disease is continued to be economically important (Pradhananga et al 2003).

Wide use of pesticides has favored the development of pathogen resistance towards pesticides. Concerns for human health and the environment have pushed the crop production to reduced use of pesticides. Host resistance plays an important role in the development of novel strategies to control bacterial wilt disease. Planting resistant varieties is the most effective and simplest methods for controlling bacterial wilt disease and also environmentally sound. Virulence differences among pathogen strains and biotic and abiotic factors can cause resistance instability in host (Hayward 1991). The least aggressive strain affects least on the resistant cultivars. Instability in host resistance appeared to be a major problem in using resistant lines (Wang et al 1997). However, effective and 
long-term disease control could be achieved with resistant or tolerant varieties as a part of integrated disease management strategies (Saddler 2005). So, the experiments were conducted in the farmers' field to evaluate the varieties and to verify their resistance to bacterial wilt that was previously reported to be resistant at Asian Vegetable Research and Development Center (AVRDC).

\section{MATERIALS AND METHODS}

Seeds of the five tomato varieties (CLN 2026 D, CLN 2026 C, CLN 1466 P, CLN 1466 J supposed to be resistant and susceptible check, L 390 were received from AVRDC, Taiwan under South Asian Vegetable Research Network (SAVERNET). In the year 1999, the experiment was conducted at Thaiba, Lalitpur (1350 masl) in naturally infested farmers field. Five varieties from AVRDC and one of the popular hybrid variety (NS 815) in that locatons in addition to susceptible check from AVRDC were included in the trial. In the following consecutive years (2000 and 2001), experiments were conducted at Panchkhal of Kavrepalanchowk (850 masl) district in naturally infested farmers field. In both the locations, the experimental fields were chosen with uniform distribution of bacterial wilt disease in previous season. The basis for determining uniform distribution of bacterial wilt disease was uniform distribution of wilted tomato plants (which showed bacterial ooze in water from the cut surface) during previous season in the fields. Above five genotypes including local Lapsigede (susceptible check) were included in the experiment. Seedlings were raised under screenhouse conditions at Plant Pathology Division using steam sterilized soil to make sure of seedlings free from disease. The experimental design was randomized complete block with four replications. The number of plants per replication of each variety was 20 . Plant to plant and row to row spacing were 30 and 60 respectively. Chemical fertilizer applied was 85:20:50 kg NPK/ha in addition to $10 \mathrm{mt} / \mathrm{h}$ of compost. One month old seedlings were transplanted during first and third week of August at Thaiba and Panchkhal respectively. Agronomical practices were given as per need. Wilt incidence was recorded based on the survival of the plants every 7 days interval until disease became stable. Ripened fruits were harvested by hand plucking and calculated in terms of $\mathrm{t} / \mathrm{h}$. Marketable and unmarketable fruit yield due to late blight were separated. For determining the size of the fruit, average of 10 fruits were taken. Three sprays of $0.15 \%$ Krilaxyl (metalaxyl $8 \%$ plus mancozeb 64\%) were given to save plants from Late Blight disease. Area under disease progress curve (AUDPC) for promising varieties at Panchkhal were calculated according to Shanner and Finney (1977) using following formula.

$$
\operatorname{AUDPC}=\sum_{\mathrm{i}=1}^{\mathrm{n}}\left[\left(\mathrm{y}_{\mathrm{i}+1}+\mathrm{y}_{\mathrm{i}}\right) / 2\right]\left[\mathrm{x}_{\mathrm{i}+1}-\mathrm{x}_{\mathrm{i}}\right]
$$

where, $\mathrm{yi}=$ disease index or incidence at the $\mathrm{i}^{\text {th }}$ observation, $\mathrm{xi}=$ time at the $\mathrm{i}^{\text {th }}$ observation, and $\mathrm{n}=$ total number of observations.

For assessing resistance level of the genotypes categorization was followed according to Mew and Ho (1976) as given below. The data were analyzed using MSTATC after transformation whenever necessary.

Resistant $\quad=$ less than $20 \%$ wilt incidence

Moderately resistant $\quad=21-40 \%$ wilt incidence

Moderately susceptible $=41-60 \%$ wilt incidence

Susceptible $\quad=61-100 \%$ wilt incidence.

\section{RESULTS}

At Thaiba, the varieties CLN $2026 \mathrm{C}$ and CLN $1466 \mathrm{~J}$ were resistant with wilt incidences, $12.8 \%$ and $24,3 \%$ respectively. Varieties, CLN 2026 D and CLN 1466 P were moderately resistant with 
wilt incidences, $21 \%$ and $30.6 \%$ respectively. Those all varieties were significantly better and are at par in response to bacterial wilt (Figure 1). Yield could not be taken due to severe infection of late blight inspite of Krilaxyl spray. However the farmers at the location were highly impressed by the higher percentage of survival (less wilt incidence) of the plants compared to susceptible check variety, L 390 (90\%) or Pusa Ruby (65\%) and popular commercial variety, NS $815(57 \%)$ of that location.

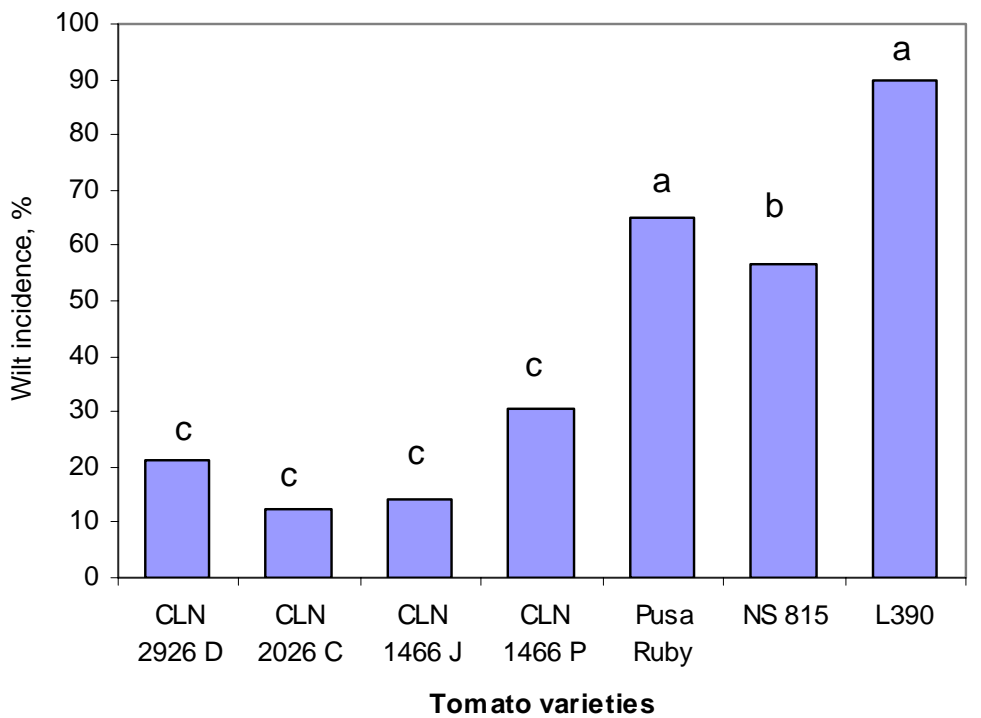

Figure 1. Onfarm evaluation of tomato varieties against bacterial wilt in the farmers' field at Thaiba, 1999. ( $C V=26.6 \%$. Column with same letter are not significantly different at $P \leq 0.05$ using DMRT)

Wilting of the tomato plants were started two weeks after transplanting in susceptible check, local Lapsigede variety in both the years at Panchkhal. In the year 2000, disease incidence was found least in CLN 2026 C followed by CLN 1466 J, CLN 1466 P and CLN 2026 D based on terminal disease incidence. The latest variety was statistically different from CLN 2026 C (Table 1). Hundred percent wilt incidence was found in local susceptible check variety, Lapsigede before fruiting stage. Regarding yield parameter, highest marketable fruit yield was found in the variety CLN 1466 P in 2000. Other three varieties CLN 2026 C, CLN 2026 D, and CLN 1466 J were not statistically different in marketable fruit yield. In fruit size, CLN 2026 C and CLN 2026 D, and CLN 1466 P and CLN $1466 \mathrm{~J}$ were at par. Lesser unmarketable fruit yield due to late bight infection was found in CLN 1466 J. Similarly in the year 2001, same trend of disease incidences were found in the test varieties. All test varieties from AVRDC were statistically similar but different from the local susceptible check in wilt reaction (wilt incidence). The disease incidence was higher in 2000 than in the year 2001, it could be due to slightly higher temperature in 2000 (more than $30^{\circ} \mathrm{C}$ ). Similarly in the year 2001, highest fruit yield was found in CLN 2026 C and it was statistically different from other rest of the tested varieties. Size of the fruit was found better in the varieties CLN $2026 \mathrm{C}$ and CLN 2026 D with medium sizes, which were closer to local Lapsigede variety (Table 1).

Table 1. Response of some promising tomato genotypes to bacterial wilt disease and yield parameters at Panchkhal during 2000 and 2001

\begin{tabular}{|c|c|c|c|c|c|c|c|c|c|}
\hline \multirow{3}{*}{$\begin{array}{l}\mathrm{S} \\
\mathrm{N}\end{array}$} & \multirow[t]{3}{*}{ Varieties } & \multicolumn{4}{|c|}{2000} & \multicolumn{4}{|c|}{2001} \\
\hline & & \multirow{2}{*}{$\begin{array}{l}\text { Wilt } \\
\text { incidence, } \\
\%\end{array}$} & \multicolumn{3}{|c|}{ Yield, t/h } & \multirow{2}{*}{$\begin{array}{l}\text { Wilt } \\
\text { incidence, } \\
\%\end{array}$} & \multicolumn{3}{|c|}{ Yield, $\mathrm{t} / \mathrm{h}$} \\
\hline & & & Marketable & Unmarketable & $\begin{array}{l}\text { Fruit size, } \\
\mathrm{g} / \text { fruit }\end{array}$ & & Marketable & Unmarketable & $\begin{array}{l}\text { Fruit size, } \\
\mathrm{g} / \text { fruit }\end{array}$ \\
\hline 1 & CLN 2026 D & $47.73 \mathrm{~b}$ & $7.25 \mathrm{~b}$ & 3.86 & $73.08 \mathrm{~b}$ & $27.13 b$ & $10.03 \mathrm{~b}$ & 2.23 & $40.6 \mathrm{~b}$ \\
\hline 2 & CLN 2026 C & $19.44 \mathrm{c}$ & $13,25 \mathrm{~b}$ & 2.36 & $71.94 \mathrm{~b}$ & $18.17 \mathrm{~b}$ & $23.00 \mathrm{a}$ & 3.6 & $46.25 \mathrm{~b}$ \\
\hline 3 & CLN $1466 \mathrm{~J}$ & $38.18 \mathrm{bc}$ & $12.25 \mathrm{~b}$ & 1.50 & $132.96 \mathrm{a}$ & $22.65 \mathrm{~b}$ & $8.92 \mathrm{~b}$ & 1.7 & $87.28 \mathrm{a}$ \\
\hline 4 & CLN 1466 P & $40.72 \mathrm{bc}$ & $21.00 \mathrm{a}$ & 2.99 & $132.41 \mathrm{a}$ & $23.59 \mathrm{~b}$ & $12.35 \mathrm{~b}$ & 1.9 & $80.4 \mathrm{a}$ \\
\hline \multirow[t]{2}{*}{5} & $\begin{array}{l}\text { Lapsigede susceptible } \\
\text { local check }\end{array}$ & $100.00 \mathrm{a}$ & - & - & - & $69.08 \mathrm{a}$ & $8.18 \mathrm{~b}$ & 1.0 & $20.75 \mathrm{c}$ \\
\hline & $\mathrm{CV}, \%$ & 17.6 & 37.51 & 43.22 & 23.35 & 51.76 & 40.34 & 71.85 & 20.19 \\
\hline
\end{tabular}


Disease progress was much faster in local susceptible check than in other varieties. Disease incidence reached nearly $90 \%$ within 4 weeks where as, the incidence was less than $25 \%$ in CLN $2026 \mathrm{C}$ during that period (Figure 2). The disease progress much slower in other varieties compared to local susceptible check. Same trend of disease progress was found in the year 2001 also, however, disease progress curves were not drawn for that year. ANOVA showed that there was no significant difference among those varieties from AVRDC in AUDPC values. Those varieties were significantly different from the local susceptible check in terms of wilt incidence. The AUDPC values for CLN 2026 C was very low and it was very high in local Lapsigede. CLN $2026 \mathrm{C}$ was at par with CLN 1466 P and J but different from CLN 2026 D in their AUDPC values (Figure 3).

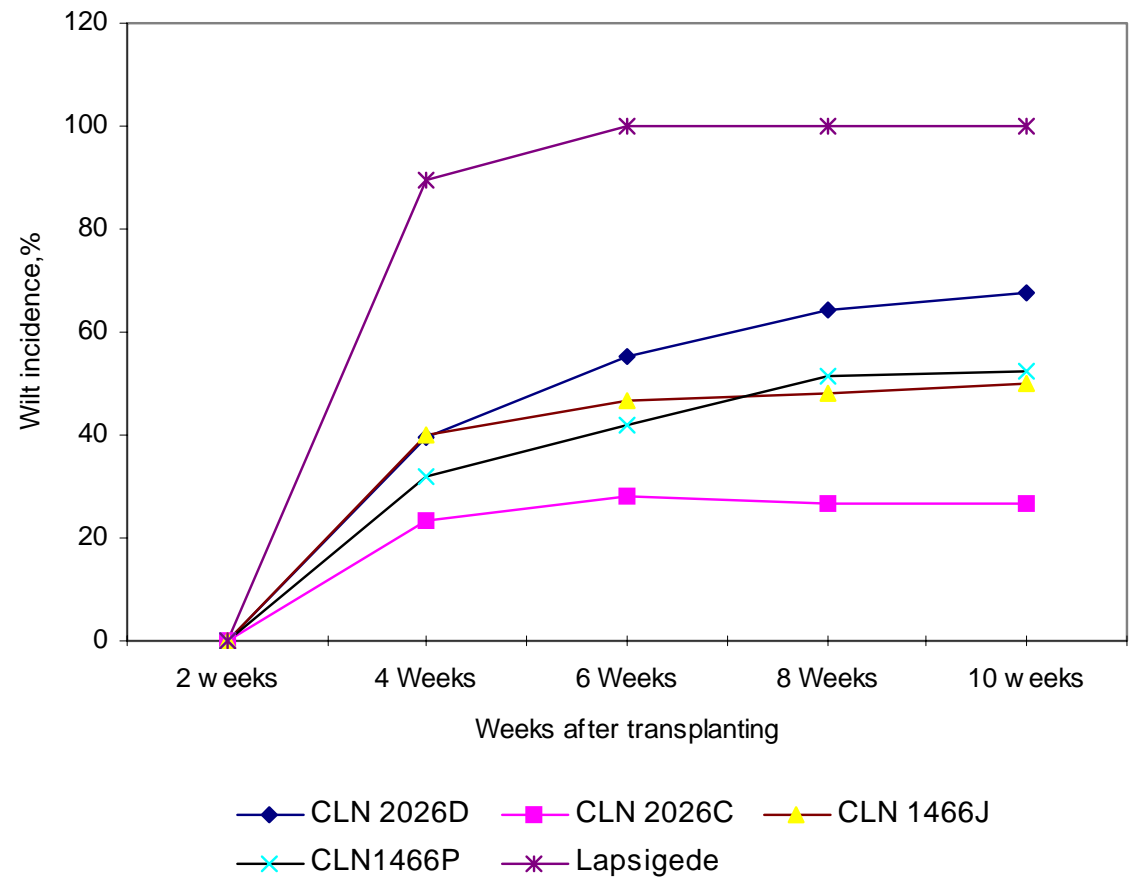

Figure 2. Disease progress curves of bacterial wilt of different promising tomato varieties at Panchkhal, Kavrepalanchowk, 2000.

\section{DISCUSSION}

Tomato is number one fruit vegetable grown in terai, foothills and the valleys of Nepal. The crop is attacked by Ralstonia solanacearum causing wilting of the plants in warm and humid conditions. The farmers experienced considerable economic losses due to this disease. Because of soil borne nature, location specific strain, wide host range with wide spread distribution and vast genetic variability (Hayward 1991), bacterial wilt disease is difficult to control once established in the field. Use of resistant variety is the most effective and simplest methods of controlling bacterial wilt (Monma and Sakata 1983), however, the genetic basis of resistance breaks down due to the changes in the host or pathogen under condition of high temperature (Mew and Ho 1977).

Four promising varieties with resistance to bacterial wilt from AVRDC were tested at Panchkhal of Kavrepalanchowk, which is one of the most bacterial wilt prone areas and at Thaiba of Lalipur where outbreak of bacterial wilt occurred in recent years. Our results showed that the varieties CLN $2026 \mathrm{C}$ and CLN $2026 \mathrm{D}$ were better than other varieties in terms of disease and yield parameters. These varieties were preferred by the farmers and the consumers as well. However, CLN $1466 \mathrm{~J}$ also showed better performance. But the limitation with this variety was bigger fruit size, which do not preferred by the consumers. Concerning fruit characteristics same type of observation was found by 
Budhathoki and Ahamad (2001). However, the yield and fruit size of Lapsigede could not be compared with the test varieties due to $100 \%$ wilt before fruiting during 2000 . Better fruit yield in CLN 2026 C and CLN 2026 D were also reported by Budhathoki et al (2004) under plastic house conditions, thus suitable for off season cultivation. In Nepal previously, the variety CL 1131 (now NCL 1) was resistance to bacterial wilt but its resistance was found to be broken at Panchkhal area (Timila and Shrestha 2001).

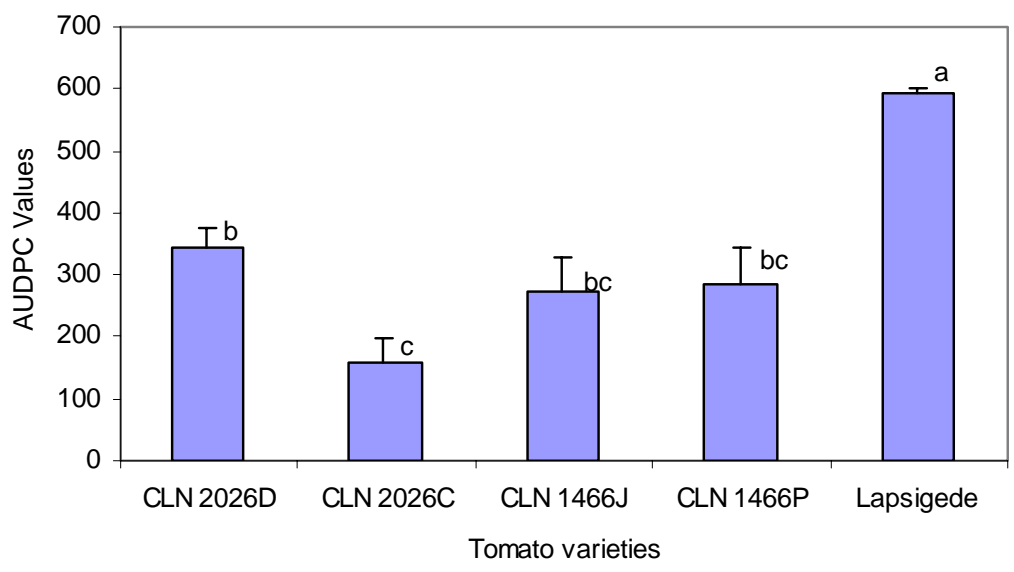

Figure 3. Area under disease progress curve (AUDPC) values for different tomato varieties at Panchkhal, 2000 (Bar indicates the standard error of the mean). CV $=24.9 \%$ Mean in the column with same letter are not significantly different at $\mathrm{P} \leq 0.05$ using DMRT.

The variety CLN 2026 C and CLN 2026 D observed to be promising in all respect, however the fruit test may not replace the local variety, such as Lapsigede which is highly preferred by the consumers. Local variety get higher price than the bigger sized fruits. The later get good price only when the supply of local tomato is less in the market. But in absence of other resistant varieties these could be cultivated as an alternative to other susceptible varieties in disease prone locations to over come the losses caused by bacterial wilt disease.

\section{ACKNOWLEDGEMENTS}

We thank Dr SK Shrestha, Former Chief Plant Pathologist, Plant Pathology Division, NARC for valuable suggestions during the coarse of experiments. Sincere thank goes to Dr JF Wang, Associate Professor, AVRDC for supplying seed and the technical suggestions. Financial supports from SAVERNET program of AVRDC is also highly acknowledged. We also express our thanks to the farmers, Mr Damodar Adhikari of Panchkhal and Mr Madhav Khadka of Thaiba for their participation, helps and availing fields for the experiments.

\section{REFERENCES}

Budhathoki K and S Ahamad. 2001. Evaluation of tomato cultivars for normal and off-season cultivation for the hills and plain conditions of Nepal. Nepal. In: Proceedings of the South Asia Vegetable Research Network (SAVERNET II) Final Workshop, 3-8 June 2001, Bangkok, Thailand. Pp. 1-10.

Budhathoki K, NG Pradhan HN Regmi and PR Bhurtyal. 2004. Evaluation of tomato cultivars for off-season production under polyhouse and open field conditions. In: Proceedings of the fourth National Workshop on Horticulture. NARI and HRD, NARC, Kathmandu. Pp. 413-418.

Hayward AC. 1991. Biology and epidemiology of bacterial wilt caused by Pseudomonas solanacearum. Annul. Rev. Phytopatho. 29:65-67. 
Kelman A. 1953. The bacterial wilt caused by Pseudomonas solanacearum. Technical Bulletin 99. North Carolina Agricultural Experiment Station. 194 Pp.

Marco Y, A Trigalet, J Vasse, J Olivier, DX Feng and L Deslandes. 2005. Host resistance to Ralstonia solanacearum. In: Bacterial wilt disease and the Ralstonia solanacearum species complex (C Allen, P prior and AC Hayward, eds). The American Phytopathological Society. Pp. 275-283.

Mew TW and WC Ho. 1976. Varietal resistance to bacterial wilt in tomato. Plant Disease Reporter 60(3):204208.

Mew TW and WC Ho. 1977. Effect of soil temperature on resistance of tomato cultivars to bacterial wilt. Phytopathology 67:909-911.

Monma S and Y Sakata. 1983. Inheritance to bacterial wilt in tomato. In: Bacterial wilt ACIAR Proceedings. No. 45. 145-153

Pradhanang PM, MT Mamol, SM Olson and JB Jones. 2003. Effects of plant essential oils to Ralstonia solanacearum population density and bacterial wilt incidence in tomato. Plant Dis. 87:423-427.

Saddler GS. 2005. Management of bacterial wilt disease.. In: Bacterial wilt disease and the Ralstonia solanacearum species complex (C Allen, P Prior and AC Hayward, eds). The American Phytopathological Society. Pp. 121-132.

Shanner G and RE Finney. 1977. The effect of nitrogen fertilization on the expression of slow-mildewing resistance in knox wheat. Phytopathology 67:1051-1056.

Shrestha K. 1990. Major diseases of vegetable crops in Nepal. Nepali book. Vegetable Development Division, HMG/Fresh Vegetable and Vegetable Seed Production Project, FAO, Khumaltar, Lalitpur, Nepal. 111 pp.

Timila RD and K Shrestha. 2001. Sources of resistance to bacterial wilt in tomato and its management approach. In: Proceedings of the First SAS/N Convention, 29-31 March 1999, Kathmandu. Society of Agricultural Scientists (SAS), Nepal. Pp. 161-167.

Timila RD, K Shrestha and S Joshi. 1997. Bacterial wilt of tomato and eggplant in Nepal. In: Proceedings of the Phase I Final Workshop of the SAVERNET. AVRDC Pubication No. 97-458. Pp. 156-167.

Vawdrey LL and Gounder RK. 1993. A glasshouse seedling test for bacterial wilt resistance in tomato. Bacterial Wilt Newsletter No. 9:3.

Wang JF, P Hanson and JA Barnes. 1997. Worldwide evaluation of an international set of resistance sources to bacterial wilt in tomato. In: Bacterial wilt disease: Molecular and ecological aspects (P Prior, C Allen and J Elphinstone, eds). Springer-Verlag, Berlin, Germany. Pp. 269-275. 